\title{
Jlomat \\ Medical Tourism in the Turkish Republic of Northern Cyprus: Strategies for Improvement
}

\author{
Oritsetimeyin Victoria Arueyingho*, Matina Ghasemi, Tulin Bodamyali
}

\begin{tabular}{|c|c|}
\hline & ABSTRACT \\
\hline rds: & Right to health" is a fundamental human right and it is protected by international laws, also $i$ \\
\hline Tedical Tourism, & urns over to states in three areas. Quality health care, affordability and the availability of \\
\hline Torthern Cyprus, & ecessary facilities and equipment's form part of the reasons why individuals in need of these \\
\hline uality Health care, & rvices migrate to countries that fortunately have upgraded facilities ready to serve the needs of \\
\hline $\begin{array}{l}\text { Medical Tourism in } \\
\text { Jorthern Cyprus, }\end{array}$ & atients worldwide. The purpose of this study is to examine the perceptions of health practitioners, \\
\hline $\begin{array}{l}\text { Northern Cyprus, } \\
\text { TRNC Tourism, Fertility }\end{array}$ & urist agents (travel agents) and hotel mo \\
\hline & Cypr \\
\hline Tourism for In & ealyzed and strategies \\
\hline Vitro & $\begin{array}{l}\text { for improving this sub-sector alongside medical tourism were proposed. The study aims to provide } \\
\text { insight for stakeholders, administrators and public officials in designing their strategies for }\end{array}$ \\
\hline$r t$ & improving this sub-sector of tourism, and to highlight the contribution of medical tourism to the \\
\hline 2021 & of North Currus . Th \\
\hline evi & \\
\hline Revised: 03.06.2021 & nalyzed using basic coding methods of qualitative analysis. Results from the first part \\
\hline & \\
\hline & ermined. \\
\hline
\end{tabular}

\section{Doi: https://doi.org/10.31822/jomat.2022-7-1-1}

\section{Introduction}

Healthcare systems are complex and there are a variety of things that a healthcare manager should know regarding its practice. A healthcare system infrastructure includes services, facilities, institutions and organizations. An adequate reaction of this infrastructure to the health problems of a population summarizes the entirety of a health-care delivery system (Stevens, Kroneman, \& van der Zee, 2017). The National Bureau of Economic Research defines a health system based on three types of arrangements between healthcare providers. These arrangements include organizations with common ownership, contractually integrated organizations and informal care systems (Jarvis, Scott, ElJardali, \& Alvarez, 2020). It has been discovered that health systems follow general patterns and this led to the development of four basic models: The Beveridge model, The Bismarck model, The National Health Insurance model and the Out of Pocket Model (Chung, 2017). The healthcare system in North Cyprus (which is similar to that of Turkey) is composed of a highly complex structure which involves the ministry of health, universities and the private sector. The most active model of healthcare in Northern Cyprus is the National Health Insurance model which is delivered by the public health care system for citizens that possess mandatory social security (Rahmioglu, Naci, \& Cylus, 2012). Many Turkish Cypriots seek health care from the private sector and high out-of-pocket healthcare expenses are also recorded. The government of Northern Cyprus has a scheme that involves the provision of free specialist healthcare in Turkey for its citizens who may be unable to afford the expenses associated with their health conditions in the private sector; therefore, they may visit public hospitals in TRNC to receive duplicate diagnoses and become entitled to free public services in Turkey (Rahmioglu, Naci, \& Cylus, 2012). Turkey is one of the highest exporters of health services and this rubs off on the Turkish Republic of North Cyprus. Turkey was the

\begin{aligned} & \hline${ }^{*}$ Corresponding Author \\ & \hline Oritsetimeyin Victoria $\begin{array}{l}\text { Pharm., Girne American University, University Drive, Karaman 99320, Girne, TRNC, Email: } \\ \text { Arueyingho: } \\ \text { timeyinarueyingho@ @au.edu.tr, Orcid Id: 0000-0003-1125-8819 iD }\end{array} \\ &$\hline Matina Ghasemi: $\begin{array}{l}\text { Asst. Prof, Girne American University, University Drive, Karaman 99320, Girne, TRNC, Email: } \\ \text { matinaghasemi@ gau.edu.tr, Orcid Id: 0000-0003-5143-1132 (D }\end{array} \\ &$\hline Tulin Bodamyali: $\begin{array}{l}\text { Prof., Girne American University, University Drive, Karaman 99320, Girne, TRNC, Email: tbodamyali@gau.edu.tr, } \\ \text { Orcid Id: 0000-0002-4364-491X (D) }\end{array} \\ &$\hline\end{aligned}


destination for approximately 560,237 international patients from 233 countries during the period 2012 to 2014 (Esiyok, Çakar, \& Kurtulmuşoğlu, 2017).

Although there are challenges associated with the health delivery systems in Northern Cyprus such as shortage of medical staff and high cost of private health insurance, the positive growth of the healthcare delivery systems in Northern Cyprus has given room for the advent of medical tourism especially in fertility treatments and reproductive health (Berkmen, 2017). Medical tourism is the process by which people who live in one country travel to another country to receive medical, dental and surgical care while at the same time receiving equal to or greater care than they would have in their own country, and are traveling for medical care because of their affordability, healthcare excluded by insurance, better access to care or a higher level of quality care (Gan, \& Frederick, 2011). It involves the combination of products and services from the tourism industry with the medical industry (Lee, Han, \& Lockyer, 2012). Traveling for health purposes is not new; however, availability of expertise and the required facilities for the diagnosis, prevention, treatment and cure of a disease contribute to the frequency of travel to a particular country. Other factors that could encourage medical tourism include cheaper health services, higher success rates, cutting-edge experimental procedures and service quality dimensions which include reliability, tangibility, responsiveness and assurance (Sultana, 2014). The rapidly growing medical travel industry has implications for the health systems of both sending and receiving countries (Whittaker, Manderson, \& Cartwrite, 2010).

Medical tourism in choice destinations would be non-existent without solid healthcare facilities and a progressive healthcare system; therefore, it is safe to say that the progressive growth of the healthcare system in North Cyprus has contributed to the industry of medical tourism. The separation of Cyprus into North and Southern states in the year 1974 grossly affected the growth rate of the healthcare system in Northern Cyprus. While the Southern side of Cyprus occupied by Greek Cypriots has experienced rapid growth, the growth of healthcare delivery systems in the North has been slower because of the embargo placed on it by the international community (Osumeje, 2015).

This paper elaborates medical tourism and its relevance alongside certain objectives such as highlighting the importance of medical tourism in
North Cyprus, why medical tourists may seek treatment in North Cyprus, the most popular treatments available in North Cyprus, exploring the status of the most attractive service within the country and diagnosing its level of performance while providing general strategies for improvement. The concept of this qualitative research is based on the theory of planned behavior; this theory aims to link beliefs to intentional behavior. Hence, responses from participants clarify intentions behind their opinions about medical tourism in Northern Cyprus, and the basic tenets of medical tourism induced by attitude, norms and behavioral control become more glaringly obvious.

\section{Research Objectives}

The study aims at exploring the current state of medical tourism with the Turkish Republic of North Cyprus as the destination country. It is not surprising to assume that the only forms of tourism available in North Cyprus involve the sun, beach and sand, however, recently North Cyprus joined the World Health Tourism Congress (WHTC) that is the most established and longest running Health and Medical Tourism Event in the World - this is a positive step in the right direction as we can all change our perspectives to include medical tourism in the achievements of this state. It is unfortunate that information related to the status of medical tourism in North Cyprus is limited, this has served as a motivating factor for the conduction of this research, not only would it be a positive contribution to health tourism education but would unveil certain loopholes within the medical tourism industry in North Cyprus.

This research aims to answer several questions, they are:

Do tourists travel to North Cyprus specifically for medical treatments?

- What are the push-pull factors that affect medical tourism in North Cyprus?

- What are the personal opinions of hotel managers, tourism agents and health practitioners on the state of medical tourism in North Cyprus?

- What procedure/medical treatment is the most utilized by medical tourists in North Cyprus?

- Using available data, what is the status of the most sought after sub-sector of the medical tourism industry in North Cyprus?

- What are possible strategies and alternatives that may be effective in alleviating problems identified within this sub-sector of medical 
Demand

Intermediaries

Supply

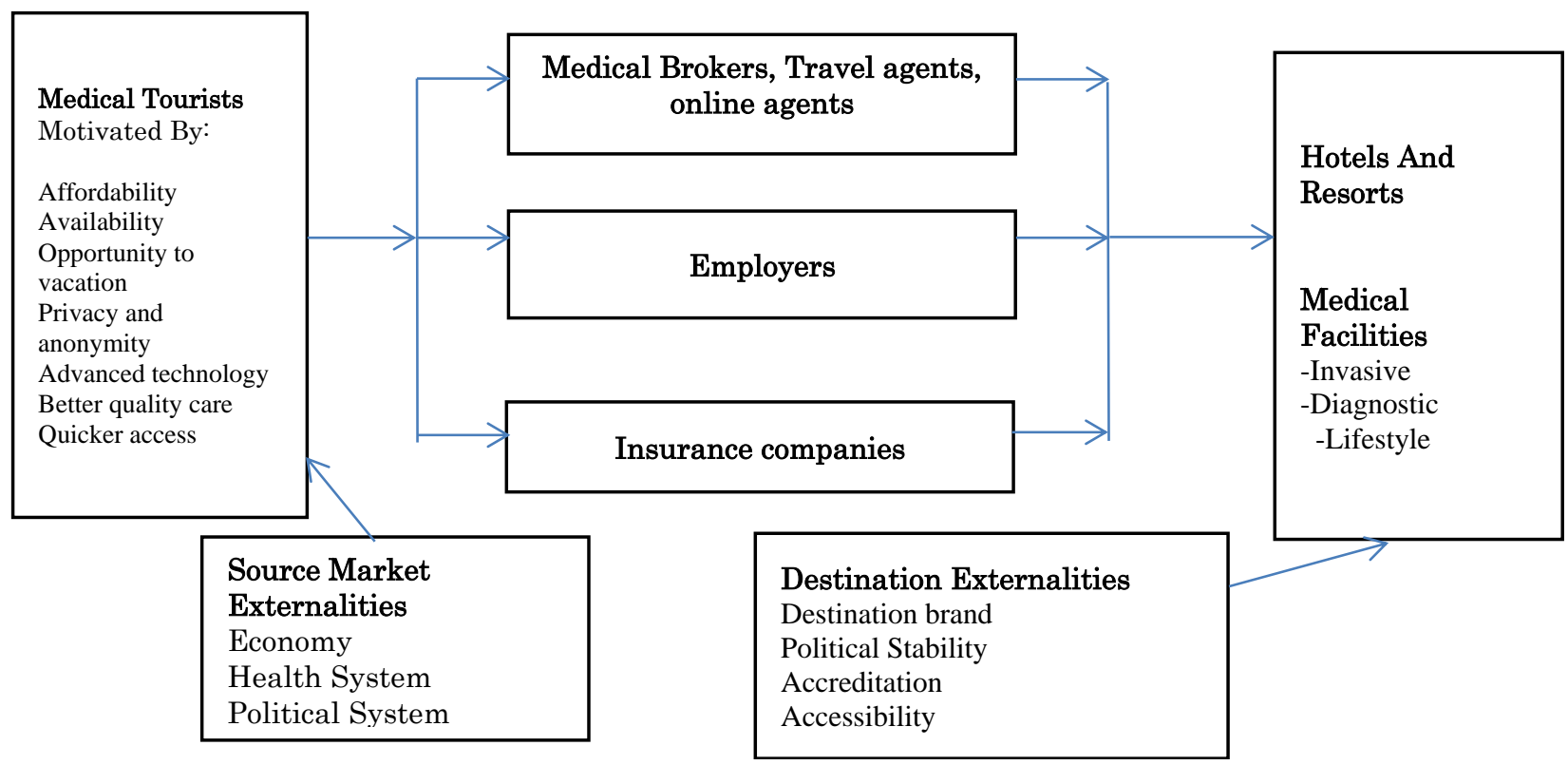

Source: (Hudson \& Li, 2012)

Figure 1: Medical tourism: An integrated model

tourism and medical tourism as a whole in North Cyprus?

- What is the contribution of medical tourism to the development of health systems in the Turkish Republic of North Cyprus?

\section{Theoretical Framework of the Study}

Medical tourism relies on several theories, most notably those covering behavior. One of these theories includes the theory of planned behavior which is intended to explain the ability of an individual to engage in a specific behavior at a specific time. The key component of this model is behavioral intent. This theory can be applied to determine the intentions of individuals to participate in medical tourism (Ramamonjiarivelo, Martin, \& Martin, 2015). Several researchers built on the few existing models of medical tourism and developed an integrated model that is aimed at guiding future research, depicting demand and supply perspectives and bridging intermediaries (Hudson \& Li, 2012). This model showcases a relationship between medical and tourism stakeholders. The left side of the model depicts medical tourists who are influenced by affordability, availability, the opportunity to travel, privacy and anonymity, advanced technologies and better-quality care, while the right side of the model illustrates the supply side of medical tourism, the influence of hotels and resorts on medical tourism (Hudson \& Li, 2012)
Another study conducted recommended that any study of domestic medical tourism should take into consideration the supply and demand perspectives of medical tourism to reveal the potential for medical tourism in a particular region (Heung, Kucukusta, \& Song, 2010). This research by identifying the push-pull factors of medical tourists and assaying available data; would be able to achieve this feat.

\section{Limitations}

The limitations of this study are highlighted below:

- Limited relevant data on the status of medical tourism in Northern Cyprus

- Limited access to respondents (Hence, reliance on snowball and convenience sampling methods)

- Inadequate sample size and choice of subjective qualitative coding methods 


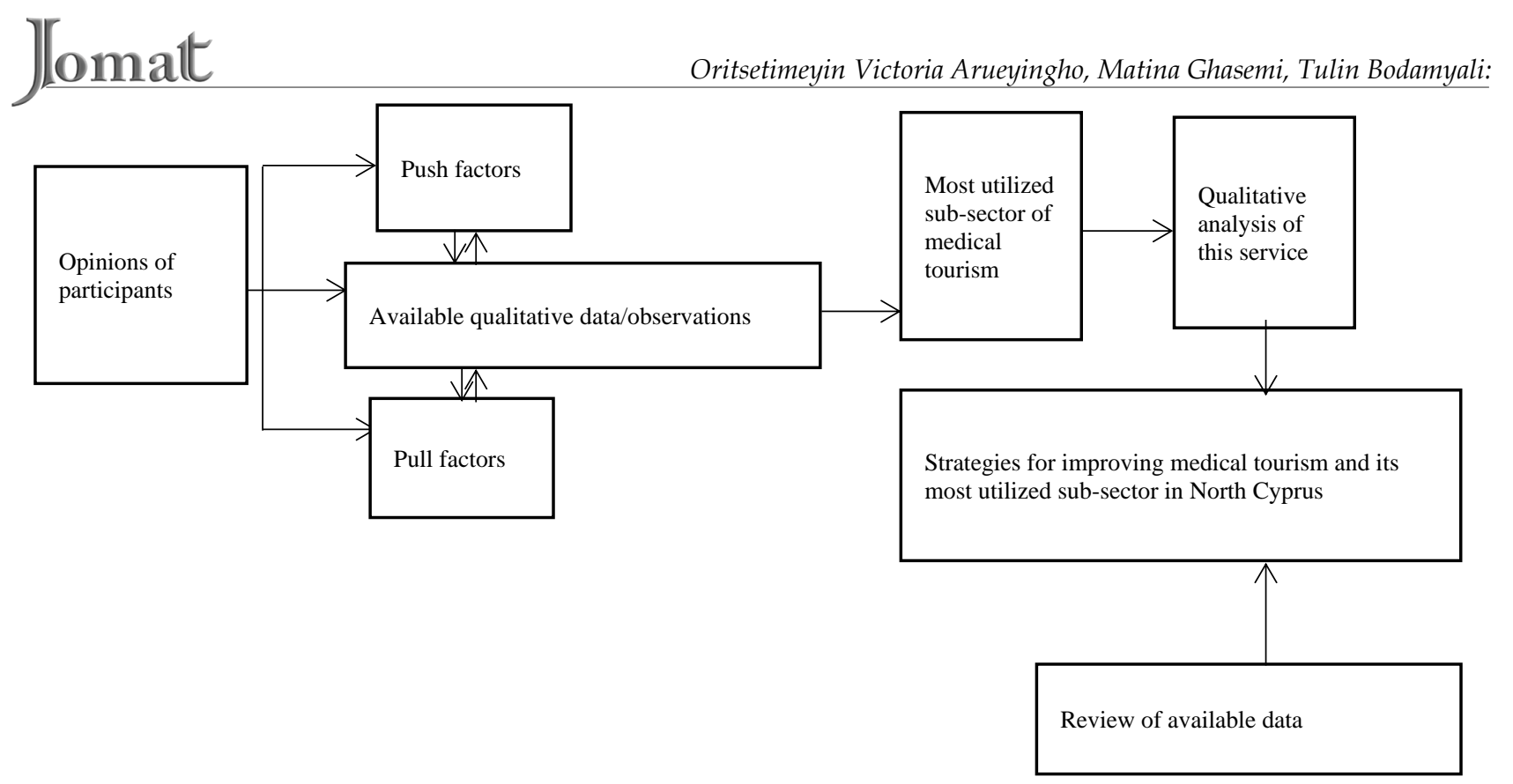

Source: Author

\section{Literature Review}

Tourism itself may be difficult to define, but its notion is based on spending time away from home in pursuit of several activities like recreation, while taking advantage of the commercial provision of services (Walton, 2012). When it overlaps with other activities, interests and processes such as medicine (for example); it leads to the introduction of different categories and in this case- medical tourism. Medical tourism is also known as international medical travel and it involves patients who seek medical attention in other countries at relatively low cost, lesser delay and the inconvenience of being placed on a waiting list (Rogers, 2011).

\section{The Health Care system of The Turkish Republic of North Cyprus}

Health care systems are complex and are comprised of several building blocks which are not independent of each other; basically it is an organization of institutions, resources and individuals that deliver health care services to meet the health care needs of targeted populations. The building blocks of an ideal health care system include health service delivery, health workforce, information systems, financial systems, governance and access to essential medicines. Drawbacks in either of these blocks could affect overall performance and sustenance of the health care system in assessment. The healthcare system of the Turkish Republic of North Cyprus would be summarized under the headings of the building blocks (WHO, 2010).
Health service delivery is a building block of healthcare systems in which patients receive the treatment and supplies that they warrant, either with their personal finances, health insurance or some type of aid. According to the American Academy of Family Physicians (AAFP), the primary goal of an exemplary health care delivery system should be to encourage optimal health outcomes by providing moderate, patient-oriented, quality care with an emphasis on service. Healthcare service delivery is made available in the Turkish Republic of North Cyprus through several pathways which include the public health care system (which is made available to those who have social security insurance), the private sector (which exposes high out-of-pocket health care expenditures), the assessment of public services in Turkey (this is made possible through a formal scheme organized by the TRNC government to send individuals for free to Turkey for specialist care if the required services are unavailable) and the formal crossing of the border to receive public services in South Cyprus (Rahmioglu, Naci, \& Cylus, 2012).

Another building block of the health care system is the health workforce, A sturdy workforce in the health sector would facilitate the ability of a country to meet its health goals; it is an added trump card if the available workforce are inspired, equipped, knowledgeable and properly skilled in handling circumstances evident within their command. There is minimal available statistics on the health workforce of TRNC; this is partially due to its ambiguous status that has affected 
investments from EU- and US-based hospital companies (Gauldie, 2017).

Health Information systems (HIS) is another building block of an ideal health system and predominantly, information regarding the HIS of countries can be obtained from agencies responsible for generating, compiling and analyzing the data. The Organization for Economic Co-operation and Development (OECD) serves to stimulate world trade and economic progress; they publish reports and statistics on a wide number of subjects for its 37 member countries. The TRNC is neither a member of the European Union nor the OECD, hence it is twice as difficult to retrieve reliable information of international standard; most health related data are published on the website of the state's ministry of health, Kuzey Kıbrıs Türk Cumhuriyeti Sağlık Bakanlığı and the state planning organization.

Access to essential medicines is a building block of a health care system and the World Health Organization defines them as medicines that satisfy the priority health care needs of the population. Essential medicines are supposed to be affordable and easily accessible, while accessibility may not be a problem in TRNC as there are a lot of community pharmacies, affordability and availability have proven to be quite a challenge especially for average Turkish-Cypriot residents in need of orphan drugs (Gokcekus, Toklu, Demirdamar, \& Gumusel, 2012). Although prescriptions/medicine costs are cheaper when compared with other European countries, lack of data and high out-of-pocket expenditure has made it difficult to draw conclusions or make comparisons. The ministry of tourism and social media experts are therefore making great efforts to leverage the privacy, affordability (when compared to other European countries), short waiting lists and beautiful climate of the country, using them as pull factors of attraction (Altinay, \& Hussain, 2005).

\section{History and Growth of Medical Tourism}

The practice of traveling for health and medical reasons is not new. The idea of medical tourism backdates to the Sumerians in 4000B.C (Mestrovic, 2018) but an all-inclusive health tourism system was developed by the Greeks (Benzler, 2013). The antique concept of medical tourism has however evolved from the use of mineral-rich water (spas) to surgical operations, fertility treatments and clinical experiments. Modern day tourism is believed to have started in the 1980's when health costs increased drastically in certain countries like the United States of America, patients were known to travel to other countries e.g. Costa Rica for dental surgeries not covered by their insurance (naraveeplasticsurgery.com, 2018). In the late 20th century, the government of Thailand directed its tourism officials to brand and market the country as a melting pot for plastic surgeries hoping to boost revenue, Bumrungrad International Hospital in Bangkok became one of Thailand's best known destination for medical tourists (Pickert, 2008). In the year 2017 it was recorded that approximately 35.38 million foreign tourists arrived in the country and they spent about 1.8 trillion baht (Froyd, 2018). In the early two thousands, it was reported that over 150,000 citizens of the United States traveled to Asia and Latin America, this figure has long since doubled (medicaltourism.com, 2019). Fast forward to the 21st century, data collated in the year 2018 revealed that the global medical tourism industry was valued at 16,761 million USD and it is estimated to reach 27,247.6 million USD by (mordorintelligence.com, 2019), these values represent tremendous growth of this industry.

When Turkey's traditional tourism industry dissipated, the country re-centralized its focus on the medical sector. It was reported that the influx of medical tourists in Turkey increased from 75,000 visitors in 2007 to more than 700,000 visitors in 2017 (Perryer, 2019). In the Turkish Republic of North Cyprus, it is claimed that visitors combine summer holidays with the opportunity to get IVF treatments, cosmetic or dental surgeries. In 2015, there was agreement between the North Cyprus Ministry of Health and two leading Swiss Medical associations for the purpose of increasing future Swiss health tourists as well as enabling the exchange of technology and personnel between these two countries (NCI.com, 2015).

The corona virus pandemic has had a negative impact on the state of tourism; travel restrictions, closed hotels and the desperate need for 'social distancing' have exacerbated declined travel rates, thereby affecting tourism negatively. While the management of covid19 related crises has been paid attention to by academics, there is little information on the possibility of tourism (medical) as a panacea for destination recovery (Abbaspour, Soltani, \& Tham, 2021). The tourism industry, specifically medical tourism, may take a long time to be resuscitated, but this does not negate the fact that it may return to its former glory (Khan, Chauhan, Majeed, \& Goyal, 2020). 
Push-Pull Factors of Medical Tourism

There are several factors that encourage medical tourism; these factors are particular to the residential country of the medical tourist. These can be divided into push and pull factors, push factors drive people away from a place while pull factors attract people (IHRC, 2014). They are psychological motivations that may influence the behavior of a tourist. A new model of medical tourism has been designed to guide research, while taking into consideration the psychological factors that affect the behavior of tourists, perspectives of demand and supply were depicted alongside intermediaries that bridge them. The model stands out and remains unique due to the relationship that is established between medical and tourism stakeholders ( Hudson \& Li, 2012).

The model reveals a left and right side which are divided by intermediaries. The left side represents medical tourists who are motivated by affordability, availability, opportunity to vacation, privacy and anonymity, advanced technology, better quality care and quicker access. The Turkish republic of North Cyprus offers a degree of these factors, most especially opportunity to vacation and privacy, advanced technologies are available but may be limited while quicker access is inhibited by the embargo placed on the country as a whole. Supposed medical tourists willing to visit TRNC would also be influenced by the economic and political systems of their countries.

Intermediaries represent the channels through which medical tourists seek medical tourism. In the course of this research, these channels were explored and accessed to gain an insight on the presence and influx of medical tourists into TRNC. Those channels include medical brokers, travel agents and online agents; they bridge the gap between medical tourism providers and medical tourists. There are three forms of medical tourism as identified by Bookman and Bookman; they are invasive, diagnostic and lifestyle. High technological procedures are included in invasive forms of medical tourism; diagnostic procedures encompass several types of tests while wellness and recuperation treatments are enclosed in lifestyle forms of medical tourism (Medhekar, Wong, \& Hall, 2014). The right side of the model illustrates the supply side of medical tourism which includes a combination of medical tourism facilities and hotels/resorts, all offering the three forms of medical tourism.
Medical Tourism in the Turkish Republic of North

\section{Cyprus}

Cyprus is the third largest island in the Mediterranean and since 1974 Cyprus has existed in two parts: the North occupied by the Turks and the South occupied by the Greeks. North Cyprus covers an area of 3,355 square kilometers. The capital of North Cyprus is Nicosia and major cities include Kyrenia, Famagusta, Guzelyurt, Lefke and Karpaz. The skies are consistently cloudless and this encourages low humidity that makes the temperature bearable. North Cyprus is therefore promoted as an ideal location for summer and winter holidays. The new TRNC government statistics has revealed a significant growth in tourism, with increased numbers arriving from all over Europe, North America, Scandinavia and even new arrivals from China this encouraged the introduction of new hotels, traditional houses, boutique hotels and bungalows. Holiday tourism therefore blends perfectly well with medical tourism although competition is stiff due to embargoes and restrictions in transportation (Hussain, Mothiravally, Shahi, \& Ekiz, 2012).

There are over 137 travel agencies working locally with international tour operators to increase revenue. The GNP of Tourism in North Cyprus increased from 1,527,899,266 TL to $3,814,495,652.1$ TL from the years 2013 to 2018 respectively (State Planning Organization, 2018). Net revenue of $\$ 791$ million was forecasted in the tourism industry for the year 2019 compared with the net revenue of $\$ 697.70$ million generated in the year 2015 (Taşiran, \& Özoğlu, 2017). The health care industry is witnessing changes to accommodate holiday tourists who may be in need of health care.

It was reported that in 2008, doctors provided general/surgical treatments to over 45,966 people and dental cure/treatment to 22,912 patients (Health and planning office, 2008). BFN Cosmetic Tourism, a local private company located in Kyrenia in collaboration with a private hospital in Nicosia has designed healthy medical tourist packages to encourage medical tourism in Europeans (bfncosmetictourism.com, 2009). These packages include procedures such rhinoplasty, otoplasty, face lifts, breast augmentation, labiaplasty and dental surgery in combination with flight and hotel bookings, post-operative checks and airport transfers (Hussain, Mothiravally, Shahi, \& Ekiz, 2012).

In 2007, a three-day conference themed The Globalization of Medical Tourism was held in 
Amman (the capital of Jordan) under the royal patronage of King Abdullah II. The TRNC delegation was led by Fikri Ataoğlu (The Minister of Tourism and Environment) and the President of TRNC's Health Tourism Council, Ahmet Savaşan, with the aim of promoting world class health facilities to new audiences (T-VINE, 2017). It was thereafter reported that the TRNC attracts an estimate of 20000 new patients annually as the state has repeatedly worked hard in building a reputation in a number of fields such as cosmetic surgery, invitro fertilization, physiotherapy and dentistry. Tina Malone, a popular actress, was 50 years old when she gave birth in the year 2013 after receiving treatment from Dr. Gazvani at a North Cyprus treatment Centre in Famagusta (Genower, 2017). Fast forward to 2019, the Turkish Republic of Northern Cyprus participated in the third Global Health Care Forum which was held in Baku, Azerbaijan. In this forum, certain tasks were defined, such as: establishing real cooperation and support between healthcare and tourism, developing and adopting the mechanism and tactical approach of this cooperation (globalhtc.org, 2019).

A strategic analysis of medical tourism in North Cyprus was conducted several years before, findings involved a PEST and SWOT analysis that outlined possible conditions for the development of medical tourism in the future and necessary recommendations were highlighted (Hussain, Mothiravally, Shahi, \& Ekiz, 2012). A few years later, the attitudes of the stakeholders in the health tourism sector of North Cyprus towards education on health tourism were analyzed in a study conducted by Ahmet Savaşan and colleagues. It was concluded that there was limited and insufficient literature regarding health tourism education and that the stakeholders of this sector needed to be educated about the sustainable economic contributions of health/medical tourism to the country (Savaşan, Yalvaç, Uzunboylu, \& Tuncel, 2018). The perceptions of the residents of North Cyprus towards medical tourism were observed using the snowball sampling method of data collection and analyzed statistically to identify the motivational factors of the respondents, thereafter it was discovered that residents were more comfortable with the medical facilities in Turkey than on the island itself (Birader, \&Ozturen, 2019). This research paper aims to expand available knowledge by focusing on a different target group while taking into consideration that a lot of changes may have occurred over time.

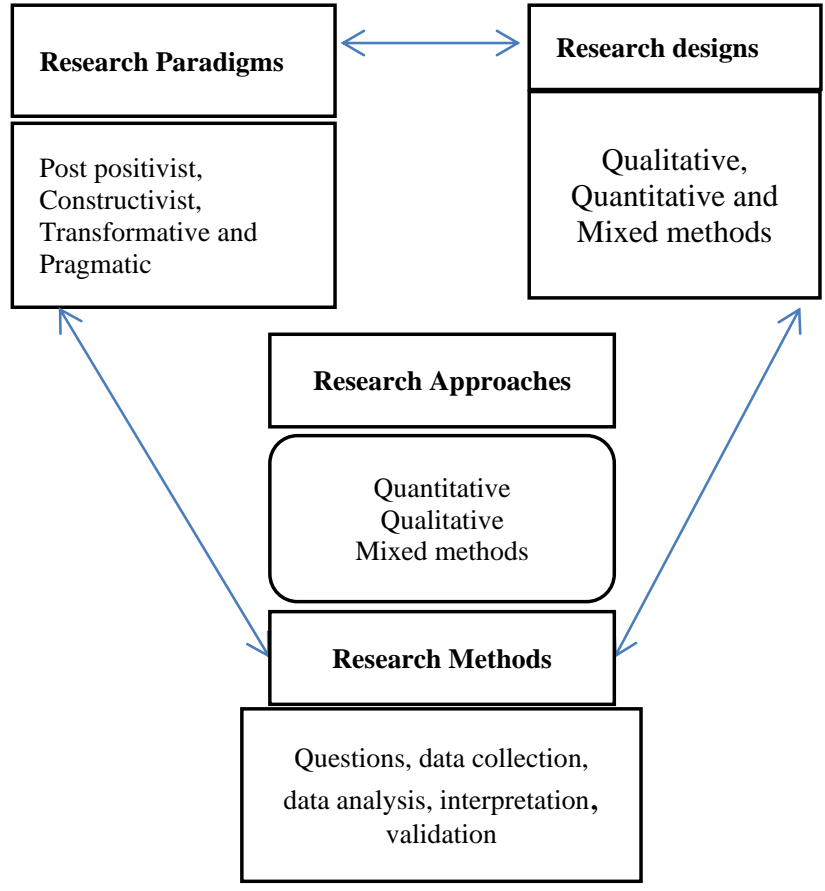

Figure 3: A framework for research Source: (Creswell, 2003)

\section{Research Methodology}

The research design framework that was used to explore this research process was devised by John Creswell. This framework is ideal because it is clear and comprehensive. The framework is composed of research paradigms, designs and research methods (Creswell, 2003).

\section{Research Paradigm}

In this research, the constructivist paradigm was used. It refers to the idea that reality is constructed via socio-environmental interactions. The focus relies on the unique qualities of the participants and their experiences; hence their views of the situation would be studied.

\section{Research Design}

There are two types of research methods; they are quantitative and qualitative research. Quantitative research involves the use of a statistical approach to quantify variables and then generalize results from the sample population, while qualitative research involves the analysis of textual, visual, or audio data and covers a broad spectrum from confirmation to exploration (Mihas, 2019). It does not only focus on "what" people think but also "why" they think the way they do (Bhat, 2019). The qualitative method of research was used for this study to observe and analyze the psychological motivators of the participants towards medical tourism in North Cyprus and their personal opinions on several questions that may help in achieving the objectives of the 
research. Qualitative observations, interviews and qualitative documents were also analyzed to aid in the research, hence, it could be said to be an observational exploratory study.

There are different models of qualitative research methods, ranging from the narrative model to the phenomenological model. The phenomenological case study model of qualitative research was essential for this study because it is aimed at developing a complete, accurate, clear and articulate description and understanding of the experiences and opinions of the focus group.

The sample of the study consisted of 30 questionnaires investigating the nature of medical tourism in North Cyprus with hotel managers, travel agents and healthcare practitioners. The survey questionnaires were prepared using openended questions, thereafter; the data was collated and analyzed using basic qualitative methods. Subsequently, structured questionnaire surveys were sent to the chief medical directors and managers of fertility clinics in Northern Cyprus using an electronic method, the purpose of these questionnaires were to reveal the strategic position of their facilities in the medical tourism industry when compared to other choice destinations.

\section{Research Methods}

A snowball sampling technique was used in the first part of this study, this non-probability method is appropriate when the target group is difficult to reach and to ease data collection. Target respondents were found in their offices and with the help of colleagues. The second part of the study involved a convenience sampling method, because although a large number of individuals were contacted, only seven participated.

\section{Data Collection}

To carry out the study, data collection was done through survey questionnaires. Thirty (30) questionnaires were given to travel agents, hotel managers and health care practitioners. The purpose of the questionnaires were explained to the respondents, thereafter they were filled and returned while their anonymity was guaranteed. The primary location of the respondents was Kyrenia, North Cyprus. The respondents included ten (10) travel agents, seven (07) hotel managers and thirteen (13) health practitioners. The duration of data collection was five months, specifically between November 2019 and March 2020 .

Thereafter, a series of structured surveys were sent to fifteen (15) fertility Clinics in North Cyprus, this is because results from the first survey revealed that fertility clinics were the most viable sector medical tourism in North Cyprus. Seven responses were received anonymously, the data was subsequently coded and grouped, while extracted information provided variables used in the evaluating push-pull factors.

\section{Data Analysis}

Responses from the first questionnaire were analyzed using basic qualitative tools which eventually established the existence of medical tourism in North Cyprus, the most viable subsector, alongside existing push-pull factors within this industry. Results from the second survey questionnaire were also coded, grouped and analyzed further. They provided more clarity on the push-pull factors of medical tourism within the state. It is intended that at the end of this study, strategies that would propel the most-viable sector of medical tourism would be provided, and they would serve as a guide for policy makers in order to strengthen other weak-links within the medical tourism industry of Northern Cyprus.

Limitations of this study include the choice of pure qualitative research methods (subjective coding analytical methods), limited access to participants, and inadequate sample size.

\section{Results}

Thirty questionnaires were filled anonymously by health practitioners, hotel managers and tourist agents; the data were thereby collated and represented below:

Table 1: Data from respondents who knew persons that had traveled from foreign countries into Northern Cyprus for medical purposes and their accommodation/length of stay.

Table 1: Data from respondents who knew persons that had traveled from foreign countries into Northern Cyprus for medical purposes and their accommodation/length of stay

\begin{tabular}{|l|l|l|l|}
\hline $\begin{array}{l}\text { If yes, clearly state the } \\
\text { accommodation type (five or four star } \\
\text { hotel; private or general hospital) and } \\
\text { length of stay (X) }\end{array}$ & & \\
& & & \\
\hline Total respondents who answered & 4 & 2 & 6 \\
\hline$\%$ of respondents who answered X & $13 \%$ & $7 \%$ & $20 \%$ \\
\hline Unsure & 1 & & \\
\hline Unsure & 1 & & \\
\hline boutique hotel, 1 week & & 1 & \\
\hline boutique hotel, few months & & 1 & \\
\hline I don't know & 1 & & \\
\hline Unsure & 1 & & \\
\hline Source: Author & & \\
\hline
\end{tabular}


Journal of multidisciplinary academic tourism 2022, 7 (1): 1-18

Table 2: Respondents opinions on the most sought after treatment options in Northern Cyprus

\begin{tabular}{|c|c|c|c|c|c|}
\hline $\begin{array}{l}\text { In your opinion, North } \\
\text { Cyprus is suitable for } \\
\text { which type of treatment? } \\
\text { (X) }\end{array}$ & $\sum$ & 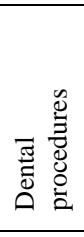 & 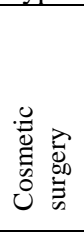 & $\begin{array}{l}\frac{n}{\Delta} \\
\frac{D}{0}\end{array}$ & $\begin{array}{l}\text { Total } \\
\text { Resp } \\
\text { onse } \\
\text { Cate } \\
\text { gory } \\
\text { Coun } \\
\mathrm{t} \\
\end{array}$ \\
\hline $\begin{array}{l}\text { Total respondents who } \\
\text { answered X }\end{array}$ & 12 & 2 & 4 & 4 & 22 \\
\hline $\begin{array}{l}\text { \% of respondents who } \\
\text { answered X }\end{array}$ & $40 \%$ & $7 \%$ & $13 \%$ & $\begin{array}{l}13 \\
\%\end{array}$ & $73 \%$ \\
\hline $\begin{array}{l}\text { botox, invitro fertilization, } \\
\text { cosmetic surgery }\end{array}$ & 1 & & 1 & & \\
\hline fertility treatment & 1 & & & & \\
\hline cosmetic surgery & & & & & \\
\hline $\begin{array}{l}\text { invitro fertilization and } \\
\text { egg donation }\end{array}$ & & & 1 & & \\
\hline IVF, ENT, IVF & 1 & & & 1 & \\
\hline $\begin{array}{l}\text { Rhinoplasty, dental } \\
\text { surgery }\end{array}$ & & 1 & 1 & & \\
\hline $\begin{array}{l}\text { eye, dentist and invitro } \\
\text { fertilization }\end{array}$ & 1 & 1 & & 1 & \\
\hline $\begin{array}{l}\text { nose job, invitro } \\
\text { fertilization }\end{array}$ & 1 & & 1 & & \\
\hline invitro fertilization & 1 & & & & \\
\hline many treatments & & & & 1 & \\
\hline $\begin{array}{l}\text { any treatment but } \\
\text { expensive }\end{array}$ & & & & 1 & \\
\hline
\end{tabular}

Source: Author
Table 3: Respondents personal opinions on their choices to either stay and/or leave TRNC

\begin{tabular}{|c|c|c|c|c|c|}
\hline $\begin{array}{l}\text { state reasons for selecting } \\
\text { your above answer } \\
\text { (question 9) (X) }\end{array}$ & 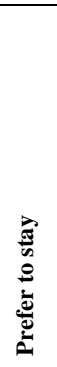 & 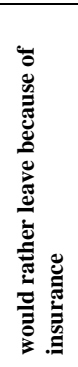 & 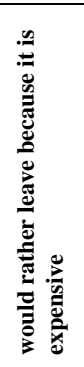 & 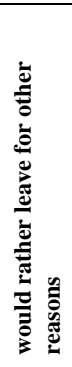 & 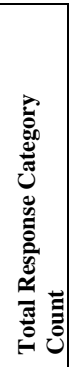 \\
\hline $\begin{array}{l}\text { Total respondents who } \\
\text { answered X }\end{array}$ & 6 & 1 & 8 & 4 & 19 \\
\hline $\begin{array}{l}\text { \% of respondents who } \\
\text { answered X }\end{array}$ & $\begin{array}{l}32 \\
\%\end{array}$ & $5 \%$ & $42 \%$ & $21 \%$ & $\begin{array}{r}10 \\
0 \%\end{array}$ \\
\hline $\begin{array}{l}\text { because Cyprus is good for } \\
\text { tourism. Treatment is } \\
\text { expensive. Does not cover } \\
\text { international people like me } \\
\text { for insurance }\end{array}$ & & & 1 & & \\
\hline VISA problem & 1 & & & & \\
\hline $\begin{array}{l}\text { I make money here, } \\
\text { insurance covers most of my } \\
\text { health needs, it is not } \\
\text { expensive except I want } \\
\text { expensive treatment }\end{array}$ & 1 & & & & \\
\hline $\begin{array}{l}\text { Very expensive. Especially } \\
\text { for cancer }\end{array}$ & & & 1 & & \\
\hline Personal & & & & 1 & \\
\hline $\begin{array}{l}\text { it is expensive. They do not } \\
\text { treat any diseases here. }\end{array}$ & & & 1 & & \\
\hline $\begin{array}{l}\text { I am Turkish. Going to } \\
\text { contry easy for me. Turkey } \\
\text { cheap too }\end{array}$ & & & 1 & & \\
\hline $\begin{array}{l}\text { it is expensive to travel. We } \\
\text { have good eye and dentist } \\
\text { clinic. Insurance covers } \\
\text { basic disease }\end{array}$ & 1 & & & & \\
\hline $\begin{array}{l}\text { Kibris expensive. Not many } \\
\text { procedures }\end{array}$ & & & 1 & & \\
\hline $\begin{array}{l}\text { many hospital. Many } \\
\text { surgeries here. I am not sick. } \\
\text { Health insurance covers }\end{array}$ & 1 & & & & \\
\hline $\begin{array}{l}\text { expensive to travel and } \\
\text { many specialist hospitals } \\
\text { abroad }\end{array}$ & & & 1 & & \\
\hline not many hospitals here & & & & 1 & \\
\hline $\begin{array}{l}\text { Kibris expensive. More } \\
\text { opportunities in Turkey }\end{array}$ & & & 1 & & \\
\hline $\begin{array}{l}\text { it is my home. I make } \\
\text { money here.treatments } \\
\text { available }\end{array}$ & 1 & & & & \\
\hline $\begin{array}{l}\text { Expensive. Insurance does } \\
\text { not cover many sicknesses }\end{array}$ & & 1 & & & \\
\hline $\begin{array}{l}\text { traveling is expensive and } \\
\text { plenty facilities in kibris }\end{array}$ & 1 & & & & \\
\hline $\begin{array}{l}\text { Better care in countries like } \\
\text { India. Cheaper. More } \\
\text { research }\end{array}$ & & & 1 & & \\
\hline $\begin{array}{l}\text { better countries outside } \\
\text { Cyprus giving better care }\end{array}$ & & & & 1 & \\
\hline $\begin{array}{l}\text { I not leave country before. } \\
\text { Here not good for certain } \\
\text { treatments }\end{array}$ & & & & 1 & \\
\hline
\end{tabular}
Source: Author

A simple grid with coded data was prepared to collate and adequately represent the data provided in the questionnaire. The letters HM were used to 


\section{lomat}

represent hotel managers, TA for tourism agents and the letters HP were used to represent health practitioners. Yes or No questions were represented with $\mathrm{Y}$ and $\mathrm{N}, \mathrm{R}$ refers to respondents and questions were represented with numbers 2,3 , 7 and 11. Percentages were used to represent the number of people who consented to different options.

Table 4: Coded grid showing responses to the questionnaire

\begin{tabular}{|c|c|c|c|c|c|}
\hline & Position & 2 & 3 & 7 & 11 \\
\hline R1 & TA & $\mathrm{Y}$ & $\mathrm{Y}$ & $\mathrm{Y}$ & $\mathrm{N}$ \\
\hline R2 & HM & $\mathrm{N}$ & $\mathrm{N}$ & $\mathrm{Y}$ & $\mathrm{N}$ \\
\hline R3 & HM & $\mathrm{N}$ & $\mathrm{Y}$ & $\mathrm{Y}$ & $\mathrm{N}$ \\
\hline R4 & TA & $\mathrm{N}$ & $\mathrm{N}$ & $\mathrm{Y}$ & $\mathrm{N}$ \\
\hline R5 & $\mathrm{TA}$ & $\mathrm{N}$ & $\mathrm{N}$ & $\mathrm{Y}$ & $\mathrm{N}$ \\
\hline R6 & HM & $\mathrm{Y}$ & $\mathrm{N}$ & $\mathrm{Y}$ & $\mathrm{N}$ \\
\hline R7 & $\mathrm{HP}$ & $\mathrm{Y}$ & $\mathrm{Y}$ & $\mathrm{Y}$ & $\mathrm{N}$ \\
\hline R8 & $\mathrm{HP}$ & $\mathrm{Y}$ & $\mathrm{N}$ & $\mathrm{Y}$ & $\mathrm{N}$ \\
\hline R9 & $\mathrm{HP}$ & $\mathrm{Y}$ & $\mathrm{Y}$ & $\mathrm{Y}$ & $\mathrm{N}$ \\
\hline R10 & TA & $\mathrm{Y}$ & $\mathrm{Y}$ & $\mathrm{Y}$ & $\mathrm{N}$ \\
\hline R11 & $\mathrm{HP}$ & $\mathrm{Y}$ & $\mathrm{N}$ & $\mathrm{Y}$ & $\mathrm{N}$ \\
\hline R12 & $\mathrm{HP}$ & $\mathrm{Y}$ & $\mathrm{N}$ & $\mathrm{Y}$ & $\mathrm{Y}$ \\
\hline R13 & HP & $\mathrm{N}$ & $\mathrm{N}$ & $\mathrm{Y}$ & $\mathrm{N}$ \\
\hline R14 & $\mathrm{HP}$ & $\mathrm{Y}$ & $\mathrm{Y}$ & $\mathrm{Y}$ & $\mathrm{N}$ \\
\hline R15 & $\mathrm{HP}$ & $\mathrm{Y}$ & $\mathrm{Y}$ & $\mathrm{Y}$ & $\mathrm{N}$ \\
\hline R16 & TA & $\mathrm{N}$ & $\mathrm{N}$ & $Y$ & $\mathrm{~N}$ \\
\hline R17 & HM & $\mathrm{N}$ & $\mathrm{N}$ & $\mathrm{Y}$ & - \\
\hline R18 & TA & $\mathrm{N}$ & $\mathrm{N}$ & $\mathrm{Y}$ & $\mathrm{N}$ \\
\hline R19 & HM & $\mathrm{N}$ & $\mathrm{N}$ & $\mathrm{Y}$ & $\mathrm{N}$ \\
\hline R20 & $\mathrm{HP}$ & $\mathrm{N}$ & $\mathrm{N}$ & $\mathrm{Y}$ & $\mathrm{N}$ \\
\hline R21 & TA & $\mathrm{Y}$ & $\mathrm{Y}$ & $\mathrm{N}$ & $\mathrm{N}$ \\
\hline R22 & TA & $\mathrm{Y}$ & $\mathrm{Y}$ & $\mathrm{N}$ & - \\
\hline $\mathbf{R 2 3}$ & HM & $\mathrm{Y}$ & $\mathrm{N}$ & $\mathrm{Y}$ & $\mathrm{Y}$ \\
\hline R24 & $\mathrm{HP}$ & $\mathrm{N}$ & $\mathrm{Y}$ & $\mathrm{N}$ & $\mathrm{Y}$ \\
\hline R25 & $\mathrm{HP}$ & $\mathrm{Y}$ & $\mathrm{N}$ & $\mathrm{Y}$ & $\mathrm{N}$ \\
\hline R26 & TA & $\mathrm{Y}$ & $\mathrm{Y}$ & $\mathrm{N}$ & $\mathrm{Y}$ \\
\hline R27 & TA & $\mathrm{Y}$ & $\mathrm{N}$ & $\mathrm{N}$ & $\mathrm{N}$ \\
\hline R28 & HP & $\mathrm{Y}$ & $\mathrm{Y}$ & $\mathrm{N}$ & $\mathrm{N}$ \\
\hline R29 & HM & $\mathrm{Y}$ & $\mathrm{N}$ & $\mathrm{Y}$ & $\mathrm{Y}$ \\
\hline R30 & HP & $\mathrm{N}$ & $\mathrm{Y}$ & $\mathrm{Y}$ & $\mathrm{Y}$ \\
\hline
\end{tabular}

Viable procedures available in TRNC

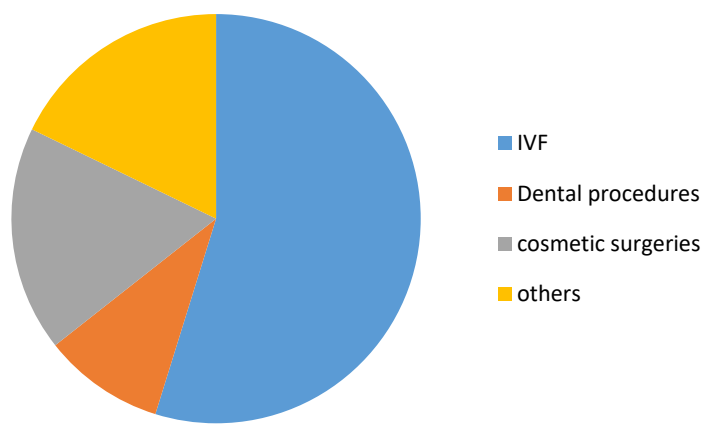

Figure 4: Viable procedures available in the Turkish Republic of North Cyprus

A simple grid with coded data was also prepared to collate and adequately represent the data provided in the second questionnaire.

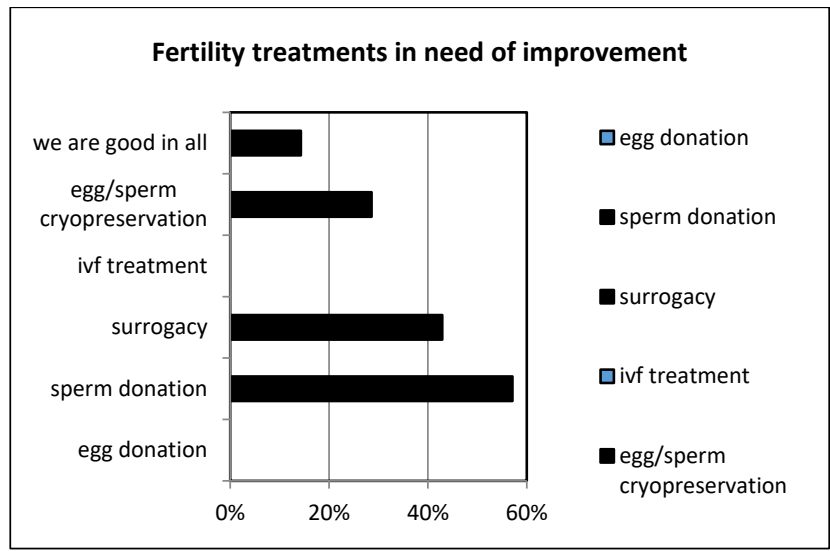

Figure 5. Areas of fertility treatments in need of improvement Source: Author

Table 5: Coded grid showing responses to second questionnaire

\begin{tabular}{|c|c|c|c|c|c|c|c|}
\hline $\begin{array}{l}\text { Popular } \\
\text { treatment? }\end{array}$ & $\begin{array}{l}\text { Waiting } \\
\text { list }\end{array}$ & $\begin{array}{l}\text { Medical } \\
\text { tourists? }\end{array}$ & $\begin{array}{l}\text { Marketing } \\
\text { team? }\end{array}$ & Target countries? & Need for improvement? & $\begin{array}{l}\text { Lack of } \\
\text { professional } \\
\text { staff? }\end{array}$ & $\begin{array}{l}\text { What } \\
\text { department? }\end{array}$ \\
\hline IVF with ICSI & SWL & $\bar{Y}$ & $\mathrm{Y}$ & $\begin{array}{l}\text { The UK, Russia, France } \\
\text { and neighboring European }\end{array}$ & We are good in all & $\mathrm{N}$ & $\mathrm{N}$ \\
\hline ED & SWL & $\mathrm{Y}$ & $\mathrm{Y}$ & WW & SG & $\mathrm{N}$ & $\mathrm{N}$ \\
\hline ED & SWL & $\mathrm{Y}$ & $\mathrm{Y}$ & WW & SG & $\mathrm{N}$ & $\mathrm{N}$ \\
\hline ED & SWL & $\mathrm{Y}$ & $\mathrm{Y}$ & $\begin{array}{l}\text { WW but specifically the } \\
\text { UK }\end{array}$ & SD & $\mathrm{N}$ & $\mathrm{N}$ \\
\hline OR & SWL & $\mathrm{Y}$ & $\mathrm{Y}$ & $\begin{array}{l}\text { Everywhere. We have } \\
\text { agents in Turkey, UK, } \\
\text { France, and Germany }\end{array}$ & SD & $\mathrm{N}$ & - \\
\hline $\mathrm{CS}$ & SWL & $\mathrm{Y}$ & $\mathrm{Y}$ & the UK & SD, egg/sperm CP & $\mathrm{N}$ & $\mathrm{N}$ \\
\hline IVF F & SWL & $\mathrm{Y}$ & $\mathrm{Y}$ & ALL & SD, SG, egg/sperm CP & $\mathrm{N}$ & - \\
\hline
\end{tabular}




\section{Discussion}

The objectives of this research would reveal the current state of medical tourism in the Turkish Republic of North Cyprus. While there is no concrete data and statistical proof to defend the presence and population of medical tourists in TRNC, it is inarguably true that several individuals travel to Northern Cyprus specifically for medical purposes. Several intermediaries such as direct traveler (winner of eight travel awards), promote medical services in North Cyprus alongside their holiday tourism plans. General awareness of the existence of medical tourism in Northern Cyprus was also reported. While $40 \%$ of the entire population claimed to not be aware of medical tourism in Northern Cyprus, 30\% of health practitioners, $20 \%$ of tourism agents and $10 \%$ of hotel managers were confident about Northern Cyprus being a medical tourism destination. Results from the questionnaire also revealed that $20 \%$ of the respondents knew someone or several persons who had visited the island for medical purposes, while 13\% were unsure of their length of stay and accommodation type, $7 \%$ seemed to remember that most of these tourists stayed in boutique hotels and were available for several weeks to a few months. Knowledge about the existence of medical tourism in North Cyprus seemed poor as only $60 \%$ of the respondents were aware that tourists visited the country specifically for medical reasons, 33\% of these respondents were tourist agents and majority were health practitioners. Approximately $37 \%$ of these respondents proclaimed that individuals from the United Kingdom made of the largest population of medical tourists in their facilities, while $30 \%$ were unsure as they could not categorically state where the medical tourists in their facilities came from. No respondent mentioned medical tourists from Iran and the Middle East, and tourists from Africa made up the least percentage with about $10 \%$.

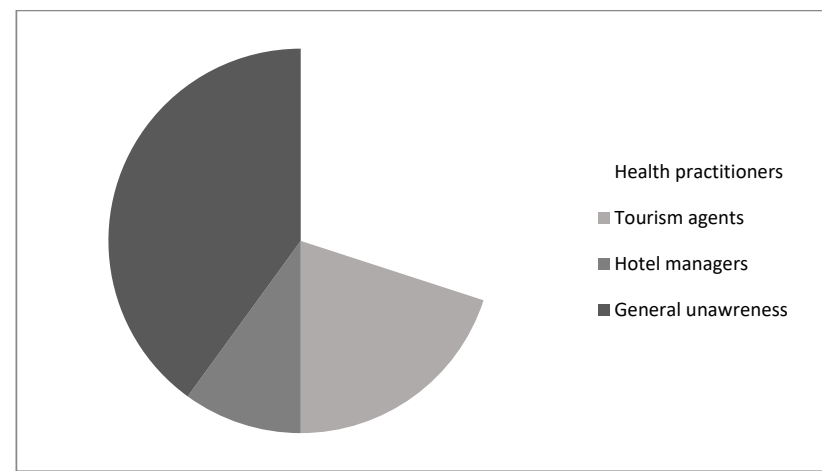

Figure 6. Level of awareness of medical tourism as reported by Source: Author
It was reported that tourism constituted approximately $8.7 \%$ to the GNP of North Cyprus in the year 2016 and currently, tourist activities represent a major aspect of economic growth (TRNC Public Information Office, 2020). Available statistics revealed that Turkey had the highest arrivals by country as at the year 2012 followed by UK-non Turkish Cypriots, and this figure increased to about 776,428 tourists in the year 2018 , however, there is no data to reveal that they came specifically for medical purposes. Respondents of this study however acknowledged that while there were visits by Turkish nationals, tourists who came specifically for medical purposes migrated from other regions. A recent study revealed that 61 out of 178 tourists who visited North Cyprus were British, and this was similar with the number of Turks who visited Northern Cyprus for tourism; 93\% of these tourists visited for purposes other than seeking medical attention (Akhavan, 2012).

\section{North Cyprus Medical Tourism Popularity by Treatment} Type

Responses to the subjective question on the type of medical procedures that attracted foreigners to the Turkish Republic of Northern Cyprus were recorded. $40 \%$ of those who responded $(73 \%$ of the entire population) to the fourth question on the first questionnaire claimed that IVF procedures were the most popular, $13 \%$ of the responses highlighted cosmetic surgeries, while $7 \%$ claimed they were dental procedures, the remaining $13 \%$ of the responses included a variety of other procedures.

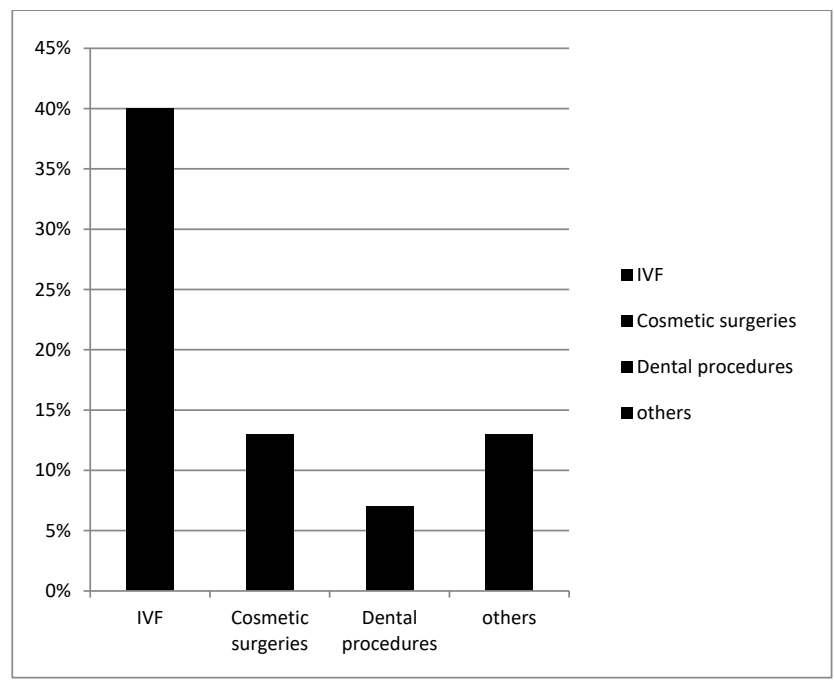

Figure 7. Most popular medical procedures in Northern Cyprus

Source: Author 
A comparative analysis between Northern Cyprus and other major medical tourism destinations may provide an insight into the performance of this defacto state. The market size of global medical tourism was valued at over 44.8 billion dollars in the year 2019, and although the coronavirus pandemic has grossly affected its growth, with all factors being equal, the compound annual growth rate of medical tourism is expected to be $21.1 \%$ (grandviewresearch.com, 2020). It is highly expected that Northern Cyprus would contribute positively to this growth.

Thailand was reportedly one of the most popular destinations for medical tourism in the year 2019 (grandviewresearch.com, 2020), India and Turkey also were among the most visited countries in the year 2019 for medical tourists. In Thailand, the most preferred type of treatment was cosmetic surgeries. Similarly, medical procedures like gastric bypass, hip and knee replacements were more affordable in India and were the most popular types of procedures. When compared to Northern Cyprus, there appears to be a limitation on the treatment types available within the defacto state. Legal limitations in Thailand such as unrecognition of unmarried and same-sex couples may restrict its viability as a choice destination for fertility treatments, when compared to Northern Cyprus.

\section{Thailand medical tourism market share, by treatment type, $2019(\%)$}
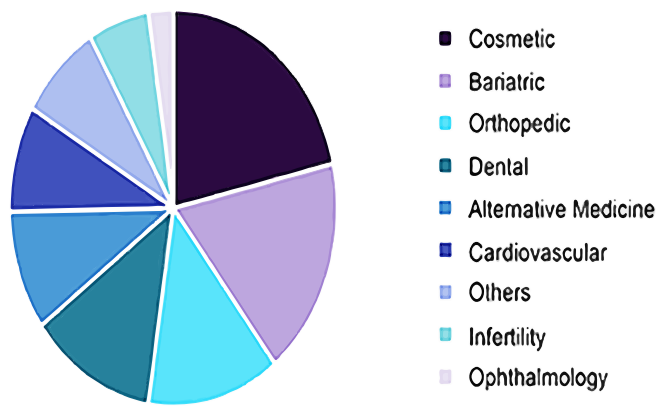

Figure 8. Thailand medical tourism market share, by treatment Source: (grandviewresearch.com, 2020)

\section{Push-Pull Motivators of Medical Tourism in Northern}

\section{Cyprus}

Responses from the questionnaire and reviews of available literature revealed certain push-pull motivators that may have affected medical tourism in North Cyprus. Several questions from the questionnaires served as key motivational indicators. It was observed that all the fertility clinics had procedures that stood out and generated the most income, although they varied per clinic, overall viability was above average. The fertility clinics also reported to have short waiting times, cheaper procedures, marketing teams, experienced staff, limited intrusion from the government and a safe environment to operate. All these could serve as solid reasons behind the attraction of foreigners into the de-facto state.

Table 6: Questions arranged in groups to highlight motivational

\begin{tabular}{|c|c|c|c|c|}
\hline QUESTION & GROUPING & 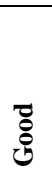 & 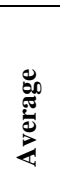 & $\ddot{\circ}$ \\
\hline $\begin{array}{l}\text { What is your most } \\
\text { popular treatment and is } \\
\text { it affordable? }\end{array}$ & Viability & $\checkmark$ & & \\
\hline $\begin{array}{l}\text { Do you have a long or } \\
\text { short waiting list and are } \\
\text { your patients promptly } \\
\text { attended to? }\end{array}$ & Waiting time & $\checkmark$ & & \\
\hline $\begin{array}{l}\text { Do you receive foreign } \\
\text { patients in the form of } \\
\text { medical tourists and } \\
\text { have you experienced } \\
\text { referrals from this } \\
\text { clientele? }\end{array}$ & Client turnover & $\checkmark$ & & \\
\hline $\begin{array}{l}\text { Do you have a } \\
\text { Marketing team or } \\
\text { agents to reach patients } \\
\text { abroad? } \\
\text { If Yes, do they excel? } \\
\text { If No, why don't you } \\
\text { have? }\end{array}$ & $\begin{array}{l}\text { Marketing and } \\
\text { Networking }\end{array}$ & $\checkmark$ & & \\
\hline $\begin{array}{l}\text { What areas do you feel } \\
\text { need improvement? }\end{array}$ & Internal factors & & $\checkmark$ & \\
\hline $\begin{array}{l}\text { Are you experiencing } \\
\text { any shortage of staff? }\end{array}$ & Staffing & $\checkmark$ & & \\
\hline $\begin{array}{l}\text { Are your staffs } \\
\text { professionally trained? }\end{array}$ & Staffing & $\checkmark$ & & \\
\hline $\begin{array}{l}\text { Are you satisfied with } \\
\text { the level of safety and } \\
\text { environment of Northern } \\
\text { Cyprus? }\end{array}$ & $\begin{array}{l}\text { Safety and } \\
\text { Environmental } \\
\text { factors }\end{array}$ & $\checkmark$ & & \\
\hline $\begin{array}{l}\text { Are there governmental } \\
\text { policies that influence } \\
\text { your work? }\end{array}$ & $\begin{array}{l}\text { Influence of } \\
\text { government policies }\end{array}$ & & $\checkmark$ & \\
\hline $\begin{array}{l}\text { Do you have the latest } \\
\text { technology? }\end{array}$ & Technology & $\checkmark$ & & \\
\hline $\begin{array}{l}\text { Does the embargo on } \\
\text { North Cyprus affect your } \\
\text { ability to receive foreign } \\
\text { patients? }\end{array}$ & Legal factors & & $\checkmark$ & \\
\hline $\begin{array}{l}\text { Do you think that there } \\
\text { is enough awareness of } \\
\text { medical tourism and that } \\
\text { it could positively affect } \\
\text { your clinic? }\end{array}$ & $\begin{array}{l}\text { Networking / } \\
\text { marketing }\end{array}$ & & & $\checkmark$ \\
\hline
\end{tabular}

Motivation is a key concept in medical tourism and it can be described as the force that drives individuals to take action, in this case, travelling to another country for medical treatments; tourist motivation is therefore now an established area of tourism research (John, \& Larke, 2016). According 
to the push-pull model, internal/psychological forces push individuals to make travel decisions and external forces of the choice destination pulls/attracts them (Walker, \& Walker, 2011). This study revealed that tourists from the United Kingdom made up the largest percentage of individuals who travelled specifically for medical reasons, what then are the push factors for these tourists? And why was the choice destination TRNC?

An article written for the daily mail titled, "Everything is legal here": British couples are being lured to a lawless 'ghost town' in Northern Cyprus where they can avoid UK law to choose the sex of their baby", revealed that gender selection was illegal in the United Kingdom but in Northern Cyprus, there would be no legal issues (Kelly, \& Allen, 2018). 40\% of the respondents agreed to the fact that majority of the medical tourists who visited TRNC came for fertility treatments and $13 \%$ for cosmetic purposes, the Turkish Republic of Northern Cyprus has therefore become a center for egg donations, the creation of designer babies and other in vitro fertilization techniques due to the lack of legal restrictions, shorter waiting times and lesser expenses.

Cosmetic procedures available in North Cyprus include rhinoplasty, areola reduction, arm lifts, breast implants, belly button reshaping, breast lifts, liposuctions, butt lifts, eye lifts, face lifts, fat transfer, facial feminization surgeries, genital reshaping and labiaplasty. Dental cosmetic procedures are also categorized under cosmetic procedures and they include dental crowns, dental implants and teeth whitening. Online reviews from Cosmetic Surgery Cyprus (CSC) revealed that medical tourists from the United Kingdom were benefactors of these services offered in TRNC. One of such reviews praised the CSC for their professional service, acknowledged the easy booking process and short waiting time, and then rendered accolades to the cosmetic doctors and the medical facilities present at Near East University Hospital. Another review by a medical tourist read, '...YYes, the price was lower than that of the UK, but that did not mean there was a compromise on the quality of work, safety and level of nursing care...' There were complaints about limited English language from the nursing staff, but this did not negatively influence the quality of service offered in this hospital (whatclinic.com, 2019). Popular cosmetic procedures such as breast lifts, liposuction and rhinoplasty cost about $£ 2500$, $£ 1808$ and $£ 2500$ in this hospital compared to about
$£ 5000-£ 7000$ in the United Kingdom, consultation with plastic surgeons is also free in most facilities in the Turkish Republic of Northern Cyprus (Thasariya, 2019).

Table 7: A classification of the cost of medical procedures in the UK, Turkey and Northern Cyprus

\begin{tabular}{|l|l|l|l|}
\hline $\begin{array}{l}\text { Medical } \\
\text { procedures }\end{array}$ & $\begin{array}{l}\text { Cost in the } \\
\text { United } \\
\text { Kingdom }\end{array}$ & $\begin{array}{l}\text { Cost in } \\
\text { Turkey }\end{array}$ & $\begin{array}{l}\text { Cost in } \\
\text { Northern } \\
\text { Cypprus }\end{array}$ \\
\hline Breast lift & $\begin{array}{l}£ 5000-7000 \\
\text { (Thasariya, } \\
2019)\end{array}$ & $\begin{array}{l}£ 2900 \\
\text { (Medical } \\
\text { Tourism in } \\
\text { Turkey, } \\
2020)\end{array}$ & $\begin{array}{l}£ 2500 \\
\text { (Thasariya, } \\
2019)\end{array}$ \\
\hline Liposuction & $\begin{array}{l}£ 5000-7000 \\
\text { (Thasariya, } \\
2019)\end{array}$ & $\begin{array}{l}£ 2200 \\
\text { (Medical } \\
\text { Tourism in } \\
\text { Turkey, } \\
2020)\end{array}$ & $\begin{array}{l}£ 1808 \\
\text { (Thasariya, } \\
2019)\end{array}$ \\
\hline Rhinoplasty & $\begin{array}{l}£ 5000-7000 \\
\text { (Thasariya, }\end{array}$ & $\begin{array}{l}£ 2900 \\
\text { (Medical } \\
\text { Tourism in } \\
\text { Turkey, } \\
2020)\end{array}$ & $\begin{array}{l}£ 2500 \\
\text { (Thasariya, } \\
2019)\end{array}$ \\
\hline 2019$)$ & $£ 2200-9700$ & $>£ 2200$ \\
\hline $\begin{array}{l}\text { Fertility } \\
\text { treatments }\end{array}$ & $>£ 5000$ & & \\
\hline
\end{tabular}

Source:

Pull factors of medical tourism in North Cyprus therefore include:

- Cheaper health care

- Lesser legal restrictions

- Shorter waiting lists

- High success rates

- Availability of optimum health care facilities

- The climatic conditions and side attractions of the country (which are essential for postoperative recovery)

However, a large population of the residents of North Cyprus would rather travel to other countries for medical purposes. $42 \%$ of the respondents complained that health care and medical procedures were rather too expensive for them (probably because the services are paid for in euros and most indigenes earn a lot less in Turkish Lira) and $21 \%$ of the respondents would rather leave for other reasons. This decision to leave may be influenced by the local economy of the de-facto nation, currently the minimum wage is officially 3150TL and many individuals are still being paid below this amount (Security, 2019). The estimated cost of living for a single person is about 2500TL per month excluding rental fees, and with poor health insurance systems and high out-of-pocket payments, achieving treatments worth thousands of Turkish Lira may be far-fetched for some individuals, cheaper medical tourist destinations may be a better option. 
Push factors of medical tourism in North Cyprus therefore include:

- Inflation and the Economy

- High expenses for residents

- Inadequate infrastructural facilities for the treatment of predominant diseases or complicated surgical procedures

- Inadequate bed spaces and health practitioners

Fertility Treatments in the Turkish Republic of Northern Cyprus

Several procedures were reported by the respondents as being the most sought after options within their fertility clinics, they include: Invitro fertilization, Egg donations, and ovarian rejuvenation, seemed to be the most popular. Egg donors are paid for their services and their anonymity is always guaranteed, as a matter of fact, the donors are not meant to know the recipients. Eurocare IVF describes this entire process on their website and state that the entire package costs about €5000/£4400 (IVF, 2021) which although is greater than the previously mentioned $£ 2200$ average, is cheaper than most hospitals in the UK that would charge approximately $£ 9000$ (eggdonationfriends.com, 2021) and Thailand that would charge approximately $\$ 6110$ (£4460) (123.clinic, 2021). Egg donors are paid depending on the number of viable eggs they are able to produce, they are usually granted routine check-ups and given necessary medications before their eggs are collected. The harvested eggs would be fertilized by single sperm cells using a procedure called intracytoplasmic sperm injections before the embryo is being transferred few days later into the uterus of the recipient, usually recipients are not told to pay an additional fee for ICSI thereby making it an attractive offer.

In addition to the availability of a wide variety of fertility treatment options and its affordability, all respondents acknowledged that they had short waiting lists. Hence, they are able to attend to patients as early as possible and they would not experience the inconvenience of waiting for a very long time. Quite frequently, young women are encouraged to donate their eggs regardless of the availability of recipients; these women are profiled according to certain requirements and paid after their eggs have been harvested. However, certain services seem to suffer as highlighted by the respondents and they include surrogacy, sperm donation and egg/sperm cryopreservation. The reasons for this were not adequately investigated, but all clinics agree that they are neither understaffed nor lacking any technical expertise.

\section{Medical Tourism: Improvement Strategies}

A medical tourism and consultant group called Mercury Advisory Group help benchmark medical tourism initiatives and new market entrants with project scoping, thereby making it easier for them to comprehend their concepts of medical tourism and strategic frameworks. They created a list that is intended to help members of the medical tourism industry work efficiently towards the development of a five-year medical tourism development strategy. Some points off this list include (Todd, 2020):

- Identifying relevant strategies, plans and programs for their medical tourism sectors and executing them with effective techniques (Singh, 2019)

- Cooperation by relevant authorities in a medical tourism destination in order to encourage development. For example in Turkey, there are national medical tourism councils or boards that coordinate all formal and informal parties which have a role in the development of the sector.

- Attraction of foreign and national investments to the medical tourism sector by way of providing different privileges such as tax incentives

- Engaging curriculum specialists and experienced professional trainers to identify training needs and develop specific learning objectives and fund training activities

- Provision of transparent prices in the form of packages for their surgical and diagnostic services. Packages often include references to services provided, and may include ground transfer and accommodation beyond the hospital stay. Failure to do this may result in a loss of clientele.

Several economic factors of the TRNC may serve as opportunities for medical tourism growth such as the absence of terrorism, low homicidal rates and freedom of the press, however inefficiency of legal frameworks in challenging regulations, poor airport connectivity, poor Intellectual property protection and poor auditing strengths and reporting standards are possible disadvantages. Organizations within an industry would therefore thrive in an enabling environment which encourages maximum security, checks and balances, good corporate governance, ICT adoption, trade openness, flexibility and macroeconomic stability. TRNC ranked 89 out of 
140 countries in the 2018 Global competitiveness report, while this is not a good position, there is still hope as governmental agencies are working tirelessly to cause an improvement even with the existence of restrictions (Hasan Amca, 2019).

Intermediaries such as tourist booking agents leverage on cheap air travel to encourage the arrival of tourists from other countries. Due to the coronavirus pandemic, air travel took a significant hit from initial over capacity to multiple restrictions. There is only one airport in Northern Cyprus and airlines such as Pegasus, Turkish Airlines, Corendon, Anadolu Jet and Sun Express all fly directly into Erçan; the governmental protection of these airlines in the wake of a global recession would determine their sustainability and survival, because most of them experienced financial problems even before the pandemic. It is highly unfortunate that revenue has been lost due to the temporary ban of quick in and off airline travel, this served as a blow to the industry of medical tourism in both Turkey and TRNC. It is however predicted that there would be a lot of delays and it would take months before air travel would return back to how it was, therefore, booking a holiday or medical trip has never been more uncertain. A recent article on medical travel highlighted the possibility of many countries having a re-think of tourism and a high certainty that medical tourism would be at the bottom of the priority list (Youngman, 2020).

The most popular form of marketing strategy used by organizations in the TRNC medical tourism industry is that of cost leadership. This form of strategy involves increasing profits by reducing costs of services/products and increasing market share by charging lower prices, while still making a reasonable profit. This type of strategy has been successfully used to attract individuals from developed countries into TRNC who unfortunately have to pay expensive health costs in their home countries.

Several alternative strategies for development and improvement could be proposed:

- Joint collaboration between the Ministries of Tourism and Health in the simultaneous promotion of the environmental/climatic pros of TRNC and the available medical resources/facilities

- Creation of policies, regulations and laws that would encourage cross-participation between ministries and guidance of affairs related to medical tourism in TRNC
- Continuous alliance with Turkey alongside promotion of TRNC related medical tourism offers, thereby making TRNC an extension of Turkey which is already a recognized tourist destination; this compensates for the current embargoes and restrictions placed on TRNC.

- Deliberate governmental input to include medical tourism education in the curricula and overall training in the ministries of tourism and health, on administration, marketing and delivery.

- Adopting health certifications and international accreditations from Turkey, e.g. Joint Commission International

- Organization of training and activities of professional development for providers of medical tourism

- Design and Implementation of database systems used to standardize transactional metrics and produce customer service outcome reports

- Aligning with Turkey to gain international safety and quality accreditations pending the recognition of TRNC as an independent country

- Development of their own International Safety Quality -accredited national accreditation system with strict verification processes

- Encouraging versatility within the healthcare practitioners in the aspect of language so as to strengthen communication with tourists

- Collaboration between hotels and hospitals so as to establish space-sharing arrangements to accommodate travelers accompanying patients and/or creating settings to encourage post-operative recovery within their facilities

- Rebranding the website of the Ministry of Tourism (Turizm ve çevre bakanlığg) to look attractive and include information on medical tourism

- Building strong ties with international health insurance companies

- Sponsoring international medical tourism events in TRNC

\section{Summary and Conclusion}

The limitations of this study did not hinder the generation of solutions and answers for the stated objectives. Responses from the questionnaire and reviewed articles revealed that individuals traveled from other countries into TRNC specifically for medical purposes, and although reliable statistics is absent, available information showed that individuals from the United Kingdom made up most of the medical tourists in Northern 
Cyprus. The research went ahead to identify the most popular procedure, push-pull motivators of medical tourism in Northern Cyprus and how these factors could be leveraged to boost medical tourism in the country.

The opinions of tourist agents, hotel managers and health practitioners were taken into consideration and it became evident that domestic economic factors do not encourage the utilization of available healthcare facilities by residents of the country. Also, cosmetic procedures and fertility treatments are the highlights of the TRNC medical tourism industry, therefore residents who are in need of other invasive treatments such as cardiac transplants may be unable to undergo such procedures due to expenses, lack of equipment's, specialized hospitals and personnel, thereby encouraging their exit to other cheaper countries. It was also observed that TRNC is a popular and reliable destination for a variety of fertility treatments, specifically egg donation, and invitro fertilization. Short waiting lists, affordability and availability, are factors that have also acted as solid pull-factors to fertility treatments within the medical tourism industry of Northern Cyprus.

In conclusion, medical tourism is still at its infancy in Northern Cyprus. It is therefore advisable for governmental and non-governmental organizations to 'put their hands to the plough' by not neglecting medical tourism which is an important sector of the tourism industry and taking advantage of resource materials such as these to increase competitive advantage and improve customer gains and/or retention.

\section{References}

123.clinic. (2021). Retrieved 2 8, 2021, from 123Clinic: https://www.123.clinic/en/clinic-search/eggdonation/thailand

2traveling. (2019). Top 10 World's best Medical Tourism Destinations in 2019. Retrieved from 2traveling: www.2traveling.com/top-10-worlds-best-medicaltourism-destinations/

Abbaspour, F., Soltani, S., \& Tham, A. (2021). Medical tourism for COVID-19 post-crisis recovery?. Anatolia, 32(1), 140-143.

Akhavan, A. (2012). An Analysis of the North Cyprus Image from the Foreign Tourists' Perceptions (Doctoral dissertation, Eastern Mediterranean University (EMU)-Doğu Akdeniz Üniversitesi (DAÜ)).

Altinay, M., \& Hussain, K. (2005). Sustainable tourism development: a case study of North Cyprus. International Journal of Contemporary Hospitality Management. 17 (3) 272-280
Benzler, D. (2013). Historical Background of Medical Tourism. Medical Tourism.

Berkmen, B. (2017). An Investigation: Opinions of Individuals on In Vitro Fertilization (IVF) Living in North Cyprus. Recent Developments in Sociology and Social Work, 237.

bfncosmetictourism.com. (2009). Cosmetic tourism in bfn cosmetics. Retrieved 2 Agust 2021 from TOURISM: www.bfncosmetictourism.com

Bhat, A. (2019). Empirical Research: Definition, Methods, Types and Examples. QuestionPro. Retrieved November 20, 2019, from https://www.questionpro.com/blog/researchdesign

Birader, T. K., \& Ozturen, A. (2019). Motivators and Perceptions of Island Residents towards Medical Tourism in Mainland. Journal of Tourism and Services, 10 (19): 164-176. https://doi. org/10.29036/jots. v10i19. 99.

Chung, M. (2017). Health Care Reform: Learning From Other Major Health Care Systems. Retrieved from

https://pphr.princeton.edu/2017/12/02/unhealthyhealth-care-a-cursory-overview-of-major-healthcare-systems/

Creswell, J. W. (2003). Research Design: Qualitative, Quantitative and Mixed Methods Approaches. Sage Publications.

eggdonationfriends.com. (2021). Retrieved 2 8, 2021, from EggDonationFriends: https://www.eggdonationfriends.com/eggdonation-uk-ivf-donor-egg-guide/

Esiyok, B., Çakar, M., \& Kurtulmuşoğlu, F. B. (2017). The effect of cultural distance on medical tourism. Journal of Destination Marketing \& Management, 6(1), 66-75.

Froyd, J. (2018). Thailand Registers International Arrival Record Amid Medical Tourism Boom. Retrieved July 4, 2020, from Tourism Review: www.tourism-review.com/thai-medical-tourismmaintains-its-success-news10621

Gan, L. L., \& Frederick, J. R. (2011). Medical tourism facilitators: Patterns of service differentiation. Journal of Vacation Marketing, 17(3), 165-183.

Gauldie, R. (2017). The Turkish Republic of Northern Cyprus and its hospital sector. International Travel and Health Insurance Journal.

Genower, E. (2017). Tina Malone shows stomach scars to IVF doctor who helped her conceive daughter. Retrieved November 12, 2019, from The Sun: www.google.com/amp/s/www.thesun.co.uk/tvands howbiz/3620037/tina-malone-shows-stomachscars-to-ivf-doctor-who-helped-her-conceivedaughter/amp/ 
globalhtc.org. (2019). The GHTC Baku Declaration, 'Health Tourism as an attractive lifestyle choice for all'. . Retrieved November 12, 2019, from Global Health Care Travel Council: www.globalhtc.org/bulletin/3526-the-ghtc-bakudeclaration-health-tourism-as-an-attractivelifestyle-choice-for-all

Gokcekus, L., Toklu, H. Z., Demirdamar, R., \& Gumusel, B. (2012). Dispensing practice in the community pharmacies in the Turkish Republic of Northern Cyprus. International Journal of Clinical Pharmacy, 34(2), 312-324. doi: 10.1007/s11096011-9605-z

grandviewresearch.com. (2020). Medical Tourism Market Size, Share \& Trends Analysis Report By Country (Thailand, India, Costa Rica, Mexico, Malaysia, Singapore, Brazil, Colombia, Turkey, Taiwan, South Korea, Spain, Czech Republic), And Segment Forecasts, 2020 - 2027. Grandview research. Retrieved from https://www.grandviewresearch.com/industryanalysis/medical-tourism-market

Hasan Amca, Y. S. (2019). Northern Cyprus Economy Competitiveness Report 2018-2019. Lefkosa: Turkish Cypriot Chamber of Commerce.

Health and Planning Office. (2008). Statistical yearbook of health: Turkish Republic of Northern, Cyprus. Nicosia: State Printing House..

Heung, V. C., Kucukusta, D., \& Song, H. (2010). A conceptual model of medical tourism: Implications for future research. Journal of Travel \& Tourism Marketing, 27(3), 236-251..

Hudson, S., \& Li, X. (2012). Domestic medical tourism: A neglected dimension of medical tourism research. Journal of Hospitality Marketing \& Management, 21(3), 227-246.

Hussain, K., Mothiravally, V., Shahi, M., \& Ekiz, E. H. (2012). Strategic analysis of medical tourism: a case study of North Cyprus. JOHAR, 7(2), 25.

IHRC. (2014). Medical Tourism: Push and Pull factors. International Healthcare Research Center. Retrieved October 2019, from https://www.healthcareresearchcenter.org/medic al-tourism-push-and-pull-factors/

IVF. (2021). What is the cost of Egg Donation in Cyprus? Retrieved 2 8, 2021, from Eurocare IVF: https://www.eurocareivf.com/faq/egg-donationfaqs/what-is-the-cost-of-egg-donation-in-cyprus/

Jarvis, T., Scott, F., El-Jardali, F., \& Alvarez, E. (2020). Defining and classifying public health systems: a critical interpretive synthesis. Health research policy and systems, 18(1), 1-12.

John, S. P., \& Larke, R. (2016). An analysis of push and pull motivators investigated in medical tourism research published from 2000 to 2016 . Tourism Review International, 20(2-3), 73-90.

Kelly, T., \& Allen, V. (2018). “Everything is legal here”: British couples are being lured to a lawless 'ghost town' in Northern Cyprus where they can avoid UK law to choose the sex of their baby". Retrieved April 5, 2020, from Daily Mail: www.dailymail.co.uk/news/article6250293/amap/British-couples-lured-lawlessghost-town-choose-sex-baby.html

Khan, U., Chauhan, C., Majeed, J., \& Goyal, R. K. (2020). The impact on medical tourism in the times of a pandemic covid-19. Parishodh Journal, 9 (3).

Lee, M., Han, H., \& Lockyer, T. (2012). Medical Tourism: Attractig Japanese tourists for medical tourism experience. Journal of Travel Tourism Marketing, 69-86.

Medhekar, A., Wong, H. Y., \& Hall, J. (2014). Medical tourism: A conceptual framework for an innovation in global healthcare provision. In Innovations in services marketing and management: Strategies for emerging economies (pp. 148-169). IGI Global. doi:DOI: 10.4018/978-14666-4671-1.ch009

Medical Tourism in Turkey. (2020). Retrieved Jauary 2021, from Elcid Tour: https://www.elcidtour.com/medical-tourism-inturkey/

medicaltourism.com. (2019). Medical Tourism. Global HealthCare Resources (Medical Tourism Association). Retrieved from www.medicaltourismassociation.com/en/medicaltourism-faq-s.html

Mestrovic, T. (2018, August). What is medical tourism history? Retrieved From: https://www.newsmedical.net/health/What-is-MedicalTourism.aspx

Mihas, P. (2019). Research and Assessment Methods. Oxford Research Encyclopaedias. doi:10.1093/acrefore/9780190264093.013.1195

mordorintelligence.com. (2019). Medical Tourism Market- Growth, Teds and Forecast (2019-2024). (2019). Mordor Intelligence. Retrieved from: https://www.mordorintelligence.com/industryreports/medical-tourism-market

naraveeplasticsurgery.com. (2018). Why Cosmetic Surgery Thailand Is Getting So Popular? Naravee Aesthetic Clinic. Retrieved August 2, 2021, from Naravee website: https://www.naraveeplasticsurgery.com/en/blog/ why-cosmetic-surgery-thailand-getting-sopopular/

NCI. (2015). North Cyprus Medical Tourism, North Cyprus International. Retrieved from: 
https://northcyprusinternational.com/northcyprus-medical-tourism/

Osumeje, B. O. (2015). Medical Tourism Potentials and Prospects: The Case of TRNC. Eastern Mediterranean University, Tourism Management. Gazimağusa: Eastern Mediterranean University.

Perryer, S. (2019). Turkey's medical tourism industry boosts visitor numbers. Business Destinations.

Pickert, K. (2008). A Brief History of Medical Tourism. Retrieved August 1, 2021, from TIME: http://content.time.com/time/health/article/0,859 9,1861919,00.html\#: :text=People\%20have\%20b een $\% 20$ traveling $\% 20$ for,is $\% 20 \mathrm{a} \% 20$ fairly $\% 20 \mathrm{mo}$ dern $\% 20$ phenomenon.

Rahmioglu, N., Naci, H., \& Cylus, J. (2012). Improving health care services in Northern Cyprus: a call for research and action. European Journal of Public Health, $22 \quad$ (6), 754-755. doi:http://doi.org/10.1093/eurpub/cks145

Ramamonjiarivelo, Z., Martin, D. S., \& Martin, W. S. (2015). The determinants of medical tourism intentions: Applying the theory of planned behavior. Health marketing quarterly, 32(2), 165179.

Rogers, K. (2011). Medical Tourism. Encyclopaedia Britannica.

Savaşan, A., Yalvaç, M., Uzunboylu, H., \& Tuncel, E. (2018). The attitudes of education, tourism and health sector managers in Northern Cyprus towards Education on Health Tourism. Quality \& Quantity, 52(1), 285-303.

Security, T. R. (2019). Retrieved December 21, 2020, from Çalışma Ve Sosyal Güvenlik Bakanlığgl: https://csgb.gov.ct.tr/en-us/Minimum-Wage

Singh, L. (2019). Medical Tourism Motivations: The Driving force. Journal of multidisciplinary academic tourism, , 4(2), 77-86. https://doi.org/10.31822/jomat.621874

State Planning Organization. (2018). Sectoral Developments in Gross National Product. Turkish Republic of North Cyprus: State Planning Organization.

Stevens, F. C. J., Kroneman, M. W., \& van der Zee, J. (2017). Health-Care Delivery Systems (S. R. B. T.I. E. of P. H. (Second E. Quah, Ed.). Oxford: Academic Press.

Sultana, A. H. (2014). Factors affecting the attractiveness of medical tourism destination: an empirical study on India- Review Article. Iranian Journal of Public Health, 867-876.

Taşiran, A. C., \& Özoğlu, B. (2017). Northern Cyprus economy competitiveness report 2016-2017. Lefkoşa, Northern Cyprus: Cypriot Chamber of
Commerce. Retrieved August 1, 2021 https://www.ktto.net/wpcontent/uploads/2017/03/KTTO2016-2017eng.pdf

Thasariya, S. (2019). popular plastic surgery prices in UK: How much does it cost in the United Kingdom. Retrieved December 7, 2020, from ehealthcare cost.

The History of Medical Tourism. (2019). Health Tourism. Retrieved from www.healthtourism.com/medical-tourism/history/

Todd, M. (2020). 30 Key Findings from Medical Tourism Benchmarking Research. Retrieved December 20, 2020, from Mercury Advisory Group: https://mercuryadvisorygroup.com/30-keyfindings-from-medical-tourism-benchmarkingresearch/

TRNC Public Information Office. (2020). Retrieved from TRNC Public Information Office: pio.mfa.gov.ct.tr

T-VINE. (2017). North Cyprus on the world health tourism map. Retrieved September 2, 2019, from T-VINE: www.t-vine.com/north-cyprus-on-theworld-health-tourism-map/

Walker, J. R., \& Walker, J. T. (2011). Tourism: concepts and practices. Pearson Education, 43.

Walton, J. K. (2012). Tourism. Britannica. Retrieved from: https://www.britannica.com/topic/tourism

whatclinic.com. (2019). Cosmetic Surgery Cyprus, Retrieved December 9, 2020, from What Clinic: https://www.whatclinic.com/cosmetic-plasticsurgery/cyprus/nicosia/cosmetic-surgery-cyprus

Whittaker, A., Manderson, L., \& Cartwright, E. (2010). Patients without borders: understanding medical travel. Medical Anthropology, 29(4), 336343.doi:www.doi.org/10.1080/01459740.2010.501 318

WHO. (2010). Monitoring the building blocks of health systems: a handbook of indicators and their measurement strategies. Geneva: WHO.

Why did North Cyprus Tourism Increase?(2019, October 7). Retrieved November 11, 2019, from North Cyprus International: www.northcyprusinternational.com/northcyprus-tourism-increase/

Wiki Travel: Northern Cyprus. (2019). Retrieved from Wiki Travel: www.wikitravel.org/en/Northern_Cyprus

Youngman, I. (2020, June 23). If cheap air fares are no more, what of medical travel? International Medical Travel Journal. Retrieved July 20, 2020, from https://www.imtj.com/articles/if-cheap-airfares-are-no-more-what-medical-travel/ 
2022, 7 (1): $1-18$

https://doi.org/10.31822/jomat.2022-7-1-1

\title{
INFO PAGE
}

\section{Medical Tourism in the Turkish Republic of Northern Cyprus: Strategies for Improvement}

\begin{abstract}
"Right to health" is a fundamental human right and it is protected by international laws, also it turns over to states in three areas. Quality health care, affordability and the availability of necessary facilities and equipment's form part of the reasons why individuals in need of these services migrate to countries that fortunately have upgraded facilities ready to serve the needs of patients worldwide. The purpose of this study is to examine the perceptions of health practitioners, tourist agents (travel agents) and hotel managers, to determine if they are aware of the present condition of medical tourism in North Cyprus, and to discover the most sought-after procedure in the country. Thereafter the status of the most sought-after procedure was analyzed and strategies for improving this sub-sector alongside medical tourism were proposed. The study aims to provide insight for stakeholders, administrators and public officials in designing their strategies for improving this sub-sector of tourism, and to highlight the contribution of medical tourism to the development of the Turkish Republic of North Cyprus. The study is based on surveys given to participants selected by a snowball sampling and convenience sampling technique. Collected data were analyzed using basic coding methods of qualitative analysis. Results from the first part of the study revealed that the most sought-after medical procedures in TRNC were invitro fertilization treatments, and in the latter part of the study, the push-pull motivators and status quo of this sector were determined
\end{abstract}

Keywords: Medical Tourism, Northern Cyprus, Quality Health care, Medical Tourism in Northern Cyprus, TRNC Tourism, Fertility Tourism, Medical Tourism for In Vitro Fertilization

\section{Authors}

\begin{tabular}{ccc}
\hline Full Name & Author contribution roles & Contribution rate \\
\hline $\begin{array}{c}\text { Oritsetimeyin Victoria Conceptualization, Methodology, Investigation, Data Curation, Writing - Original Draft, Writing - Review \& Editing, } \\
\text { Arueyingho: }\end{array}$ & $20 \%$ \\
\hline Matina Ghasemi: Writing - Review \& Editing, Supervision, & $20 \%$ \\
\hline Tulin Bodamyali: Writing - Review \& Editing, Supervision, \\
\end{tabular}

Author statement: Author(s) declare(s) that All procedures performed in studies involving human participants were in accordance with the ethical standards of the institutional and/or national research committee and with the 1964 Helsinki declaration and its later amendments or comparable ethical standards. Declaration of Conflicting Interests: The author(s) declared no potential conflicts of interest with respect to the research, authorship, and/or publication of this article

Ethics Committee Satatement: Ethics committee report is available for this research and it has been documented to the journal. 